\title{
THE WORD THAT MOVES
}

\author{
H. Welzen ${ }^{1}$
}

\begin{abstract}
This essay investigates the role of the Bible in spirituality by looking at the relationship between academic exegesis and spiritual reading, mysticism and language, Bible reading as an event in the relationship between God and human beings and liturgy as a mystagogical process.
\end{abstract}

\section{ACADEMIC EXEGESIS AND SPIRITUAL READING}

At a recent congress, Mesters (2004) reported on the experiences of a number of people in Latin America about their reading of the Bible as follows:

Fourteen participants from almost all the countries in Latin America, in a fraternal exchange of personal experiences, communicated that they are accustomed to reading and interpreting the Bible both in their personal lives and in their pastoral work. Four points were made:

1) Almost everyone had moved from a period in which the Bible was absent in their lives to a period in which the Bible became the source of a deep spiritual experience.

2) The Bible cannot work alone. It needs a human community and joyous context to release its meaning and to encourage our faith, hope and love. Many of us discovered the Bible again in contact with the people, either in Basic Ecclesial Communities (BECs), in parish pastoral activity or in the charismatic movement.

3) Concrete contact with the reality of Latin America, mainly with the poor, was and is a very important key to understanding the importance and the relevance of the Bible to our personal or community life.

4) What drew attention was that almost everyone underlined the spiritual and mystical dimension of their use of the Bible. This experience did not depend on exegetical study or on the discovery of a historical literal sense, but had to do with the contribution the Bible offers to spiritual life. Mysticism and gratuitousness characterized the reading of the Bible.

1 Dr. H.Welzen, Research Fellow, University of the Free State, Bloemfontein; and Titus Brandsma Institute, Nijmegen. 
These are four thought-provoking points. On the one hand they underscore the personal commitment to reading and interpreting $\mathrm{Bi}$ blical texts from the perspective of the reader's historical and social situation. Without this commitment, it is argued, Biblical texts do not release their meaning. A value-free reading and interpretation are regarded as being impossible. On the other hand these points reflect serious criticism of academic exegesis. In fact, the fourteen people Mesters refers to, go so far as to abandon the exegetical research of the literal and historical sense of the Bible, raising the question "Is spiritual reading of the Bible indeed incompatible with scholarly exegetical research?"

A recent thesis by Reedijk (2003) provides some suggestions for an answer to this question. His work ends with a remarkable conclusion on the validity of Biblical scholarship. Reedijk relates the lectio divina of the Egyptian desert fathers, more specifically the Collatio XIV of John Cassian, to modern Biblical research and Biblical hermeneutics. He discovers some congruity between the reading of Scripture as it happens in the lectio divina and hermeneutical insights developed in some recent research on the Bible. He thus concluded that especially present day reader-oriented study is most amenable to Cassian's aims.

Reedijk then points out how Cassian also laid down conditions for the reading of Scripture - other than is the case with most modern scholars. To Cassian the problem of discovering meaning lay with the readers rather than with the texts. Readers have to subordinate themselves entirely to the text, understanding that they are not above it, but subject to it and governed by it. With this insight, Reedijk argues that this is what is lacking in present-day Biblical scholarship where the reader fails to subject him- or herself to the text.

More is at stake, though. One could point out certain parallels between modern exegesis and lectio divina. One is that they both use the same criteria of public scrutiny and objective testing of new-found insights. Discovering truth is not a purely subjective exercise of an individual reader. In Cassian's work public scrutiny and testing assume two forms. Dialogue needs to take place between the teachers and those whom they guide. This is similar to the public nature and testing found in present-day dialogue in the scholarly community. Accordingly Reedijk calls Bible reading a communitarian process. The second point is the most remarkable: 
The truth of an interpretation is recognised by what it does to people. An interpretation that becomes visual is proof of its truth (Reedijk 2003:252; our translation).

Reedijk explains in what respect this kind of discovery of truth goes beyond that of contemporary scholarship:

Such intersubjective observation is more comprehensive than that of scientific tests, which remain equally intersubjective but are conceptual and detached. In Cassian's work the truth of an interpretation always includes ethics.

More than that,

The truth that a reader discovers in a text stands or falls by the authenticity of the reader's life, by who the reader is (Reedijk 2003:252).

But this is not all. In addition to an ethical dimension the interpretation of Biblical texts has a spiritual dimension. In Reedijk's study of Cassian's lectio divina this topic is broached when he deals with the silence of those who make the study of scriptural texts their life's work. Their silence has three dimensions (Reedijk 2003, esp. 109-111). The first dimension is that one should first put Scripture into practice before instructing others in it. This dimension of silence may be seen as a product of the ethical dimension of truth that the reader has discovered in the text. Cassian insisted on the importance of the reader's purity and he considered it impossible for impure readers to acquire spiritual knowledge of a text, however persistently and even doggedly they may pore over it. The second dimension of silence concerns the known experience that important insights have a way of obtruding themselves in the silence of the night. Silence is essential for penetrating deeply into a text. Such deep penetration into the secret of a text also has to do with the fact that it gives the text a chance to obtain a firm foothold in the reader's mind. In this we recognise the spiritual process that may be triggered by prolonged, profound contact with Biblical and mystical texts. The third dimension of silence is didactic. It pertains to the silence that makes someone a good teacher. The knowledge and wisdom that a good teacher has to offer are earned through assiduous effort and hard work. When dealing with people who want to come by such knowledge and wisdom easily, silence is the most apposite response. Caution and reticence are second nature to a good teacher. 
A number of Biblical texts, as well as some texts from the Christian tradition, show that contact with the mystery these texts refer to is not where it ends. The reading process itself is a starting point for new text formation. Being touched by the mystery of a text itself triggers text production. Sometimes it triggers a creative process in which new texts are shaped: songs, stories, sermons follow as a result. Both the text that was read and the reader's experience of it are verbalised in a new text, which carries within its newly created distinctiveness the echoes of the original text and the experience gained from it. This creative process may shed light on some forms of intertextuality, which in the methodological pluralism of our day is very much in the limelight.

Sometimes this being touched by the mystery is celebrated in a liturgical gathering. The peculiarity of these celebrations is that they are the result of having been touched by the mystery, but at the same time they cause this being touched - one becomes touched by the celebration. In the following I would like to discuss this in more depth, especially developing three points: mysticism and language; Bible reading as an event in the relationship between God and human beings and liturgy as a mystagogical process.

\section{MYSTICISM AND LANGUAGE}

Of special relevance for the interpretation of Scripture is the relationship between mysticism and language. This relationship influences the understanding of Scripture in a rather unusual manner and need more explanation now.

The complexity of the relation between mysticism and language stems from the very character of mystical experience, which is primarily an experience of breakthrough. ${ }^{2}$ The word "breakthrough" cannot be taken literally enough. A radically new experience of reality breaks through so fundamentally that no existing frameworks are adequate to contain it. They collapse. Names and words fail. The reality that presents itself is ultimate and is experienced by the mystic as absolute. It eludes every humanly designed order. Yet this ultimate real-

2 The structural elements of mystical experience are described in Steggink \& Waaijman (1985:100-108). Cf. also Waaijman (2003:57-79). 
ity directly affects the person often so profoundly as to amount to an identity change. The impact has two facets. First there is direct contact, indicated by such terms as "union," "merging," "fusion," "oneness" or "communion." Secondly, there is the breakdown and bankruptcy of existing frameworks, indicated by such terms as "absence," "night," "wilderness," "solitude" and "annihilation."

This mystical experience demands "expression" and seeks to express itself. The mystic's aporia, however, is that there are no longer any adequate means of expression, because mystical experience has broken those expressions down. Neither are there any new means of expression as yet. The new experience of ultimate reality has put an end to existing means of expression, but new possibilities have yet to dawn. This aporia of a desire for self-expression when existing means of expression are inadequate is the matrix of mystical language. Its distinctiveness lies in its paradoxical character. Negation follows affirmation. Possible and impossible comparisons are made. Parables are applied in ways that readers and listeners do not expect. Proverbs and aphorisms provide food for thought. Throughout there is the driving force of the experience that creates new language where existing language cannot articulate the ineffable.

But the aporia of mystical experience in regard to linguistic expression goes beyond the mere inadequacy of existing language. Ineffability applies to all language. No language is capable of articulating the mystic's experience, yet it insists on articulation. Mystical language expresses an essential contradiction: compulsion, yet inability. Not only is existing language inadequate; the new language born of the aporia is equally so. The Ineffable continually demands to be spoken, and so language is continually being generated, only to prove inadequate yet again.

But there is more to mystical language than just its essential aporia. While language cannot encompass the Mystery, it remains that (language) conducts us into it. For centuries reading and meditating on Biblical and mystical texts have put people in contact with the ineffable and inconceivable Mystery that is God. These texts need to be read with a spiritual attitude that is sensitive to the situation in which they originated. When that happens, a mystical movement may be started in the process of reading the texts. 


\begin{abstract}
More precisely: mystical texts seek to induce an experience in the reader that will generate love in the process of reading the text. Hence reading is not something that happens to a mystical text - taken from a dusty bookshelf for that purpose: the book (or the text) only reaches completion in the loving practice of reading. Clearly this demands a great deal both from the literary structure of the text and from the reading process. Everything should be focussed on achieving an effect of love and attachment in the reader. While reading, the person is swept along into the unfathomable depth of God's powerful love, which touches and transforms the very core of that person's nature. As a result he receives the ability to "grasp" from the inside what the text is saying. This in turn makes it possible for him — touched by God's love - to take another step on the steep road of love. In so doing the text can open itself up further and become active in the reader (Blommestijn \& Maas 2003:290-301, esp. 294-295; my translation).
\end{abstract}

Seen from this perspective, reader's response refers to much more than merely an integration of the text in, for example, an intellectual manner in the person and life of the reader. It takes seriously the spirituality of that person and the deep religious context in which it is integrated. Ultimately the reader's response is directly related to her or his relationship with and commitment to God.

\title{
3. BIBLE READING AS AN EVENT IN THE RELATIONSHIP BETWEEN GOD AND HUMAN BEINGS
}

Reading Scripture means entering into a relational event that exists between God and human beings. This is an insight that is expressed in the Bible itself. On every page of the New Testament one reads that the new religious experience - deriving from the passion, death and resurrection of Jesus the Messiah — is deepened by relating it to what Scripture offers. It also imbues old texts with new meaning.

This was also the case with earlier interpretation of the Bible. Until the advent of modern academic exegesis the methods and techniques of Bible reading always served the purposes of spiritual life. In this regard, it is illuminating to look at the useful model of lectio divina devised by Guigo II, the Carthusian, in the $12^{\text {th }}$ century.

Guigo was the ninth prior of Grande Chartreuse from roughly 1173 to 1180 . Little is known about his life. For a long time his two works, the Scala claustralium or Scala paradisi and a collection of Medi- 
tationes, were attributed to Bernard of Clairvaux (Nissen 2003:975). His model, albeit in many variations, is used to this day. ${ }^{3}$ In his Scala claustralium (Guigo II 1970:163, 81-123. The English versions of the quotations are taken from Guigo II 1981) he describes how the contemplative life correlates with the four steps of spiritual reading:

One day when I was busy working with my hands I began to think about our spiritual work, and all at once four stages in spiritual exercise came into my mind: reading (lectio), meditation (meditatio), prayer (oratio) and contemplation (contemplatio). These make a ladder for monks by which they are lifted up from earth to heaven. It has few rungs, yet its length is immense and wonderful, for its lower end rests upon the earth, but its top pierces the clouds and touches heavenly secrets (Guigo II, o.c. 67-68).

The interrelationship of the four steps or rungs is vividly depicted in the following text fragment:

Reading is the careful study of the Scriptures, concentrating all one's powers on it. Meditation is the busy application of the mind to seek with the help of one's own reason for knowledge of hidden truth. Prayer is the heart's devoted turning to God to drive away evil and obtain what is good. Contemplation is when the mind is in some way lifted up to God and held above itself, so that it tastes the joys of everlasting sweetness (Guigo II, o.c. 68).

To describe the reading process, Guigo uses the classical image of the digestive system of ruminants. In the reading process the text is first swallowed whole, then it is ruminated and chewed morsel by morsel before it can be tasted and assimilated by the body so as to feed and nourish it. The reading process probes ever deeper inwards:

Reading seeks for the sweetness of a blessed life, meditation perceives it, prayer asks for it, contemplation tastes it. Reading, as it were, puts food whole into the mouth, meditation chews it and breaks it up, prayer extracts its flavor, contemplation is the sweetness itself which gladdens and refreshes. Reading works on the outside, meditation on the pith, prayer asks for what we long for, contemplation gives us delight in the sweetness which we have found (Guigo II, o.c. 68-69).

3 Bianchi (1996), Boland (1976), Mesters (1999). Guigo's model provided crucial support for Waaijman's design of spiritual hermeneutics. Cf. Waaijman (2002: 689-773). We owe our description of lectio divina to this design. 
According to Waaijman, the four steps of the spiritual reading process as they are found in Guigo, are the middle part of a basic structure he recognises in all reading practices of spiritual writings (Waaijman 2002:702-709). The initial attitude in which the reading process is started, precedes the four steps of Guigo, whilst the continuing impact of the reading follows after the four steps. This basic structure is the starting point for the design of a spiritual hermeneutic consisting of six steps: (1) the pre-understanding; (2) the act of reading; (3) the critical analysis; (4) the theological pragmatics (corresponding to Guigo's oratio); (5) the revelation of the mystery (corresponding to Guigo's contemplatio); (6) the ongoing impact.

Each of these six points needs more discussion, because they could be a model for the preparation of liturgical services. At the same time they are a model for the interpretation of what can happen during such a service.

\subsection{Pre-understanding}

Contemporary hermeneutics indicate how important predetermining the initial attitude of readers and interpreters is for assigning meaning to texts. It is obviously important how texts present themselves to us: as a source for historical and literal research, as a text belonging to the history of culture of Western Christianity, as a holy text or as a meditative text for pious reflection. The place where a text is read is important too. This is well illustrated by Grollenberg (1992:152; my translation) who wrote,

Having started my professional study, I forgot that religious way of handling Scripture as I began focussing on the "original", on the authors of the texts and on handing over what they wanted to say. So you can call it loss of devotion. But I couldn't help feeling there was also an advantage in this. I'll start with an example. When in our celebrations a story from the Gospels, for instance from the Gospel of Matthew, was read, sometimes the minister finished the reading with saying "Word of the Lord" or "This is the Lord speaking." I often thought by myself, "But it is Matthew writing." The reason is clear. I got to know this Gospel as an elaborate work of a very special kind. Upon every passage, story or word of Jesus the evangelist put his stamp. It is in the first instance his voice that I hear. 
In this text the scholarly approach, and more specifically the historical-critical method, has taken the place of the spiritual and liturgical reading. These readings have been pushed aside by the academic approach. The study has now replaced and occupied the room of the chapel. The Word of God is not heard anymore, but only the intention of the Biblical authors.

\subsection{Reading and meditation}

The phases of reading (lectio) and meditation (meditatio) correspond to common reading and critical analysis of a text. Common reading includes all the activities involved in perusing of a text: recognising the ink marks on the page as meaningful signals, combining letters into words, words into sentences and sentences into larger textual entities. Decoding according to the code in which the meaningful signals are couched also forms part of the activity of common reading. In addition the passage has to be related to what was read previously and to what will be read next. Finally the act of common reading includes assigning meaning to the text. The meaning that readers assign to a text is not arbitrary. In their interpretation they are again directed by the signals contained in the text. The act of common reading is a circular, interactive, hermeneutical process, entailing both direction of the reader by the text and the reader's interpretive activity in relation to the text.

Everyone can feel that the common reading is an activity of the reader that assigns meaning to a text. Reading or hearing the words, "Once upon a time ..." creates a world in which goblins, elves, sorcerers, unicorns and trolls may exist. But if a novel starts with a quotation from a diary and continues with the words, "Thus, with unabashed conceit, wrote Roberto della Griva presumably in July or August of $1643, " 4$ a field of meaning is shaped in which the creatures just mentioned would at least be a little bit strange.

The activity of assigning meaning in the reading process can easily be recognised when another unexpected field of meaning is created by a certain emphasis or by a slip of the tongue, as the following examples of strange readings reveal. In a recent liturgical service that I attend

4 This is how the novel of Eco (1995) begins. 
regularly the parable of Lazarus and the rich man (Luke 16:19-31) was read. After the request of the rich man that Lazarus cool his tongue with a drop of water is rejected, he makes a new request. This was recited by the reader in the following way: "Dan, vader, vraag ik u hem naar mijn ouderlijk huis te sturen, want ik heb nóg vijf broers." The stress on the word "nog" assigns the following meaning: "Then, father, I beg you to send him to my father's house - for I have another five brothers (except for the five already suggested)." Some calculation revealed that with this simple emphasis a field of meaning came into being that suggested a family of at least eleven boys, whilst the text clearly indicates not more than six. One could also refer to the royal slip of the tongue at the presentation of the new Dutch translation of the Bible (NBV) on 27 October 2004, giving a complete new content to Genesis 1:2. The queen of the Netherlands read, "Duisternis lag over de overvloed" ("Darkness was on the face of abundance") instead of "Duisternis lag over de oervloed" ("Darkness was on the face of deep"). More striking was a reading that was caused by the fact that the phenomenon of caravans was unknown to the reader. In the story of the visit of Jesus as twelve-year-old boy to the temple of Jerusalem (Luke 2:41-52), a very unusual and anachronistic field of meaning was created. In the passage it is remarked that the parents of Jesus did not realise that Jesus stayed behind in Jerusalem. The text was read as follows: "In de mening dat hij zich bij de caravan bevond, gingen ze een dagreis ver en zochten hem toen onder familieleden en bekenden." The word that had to be read is karavaan, meaning a train of travelling people. In Dutch the word caravan means mobile home. Thus the text was understood as "Assuming that he was in the mobile home of travelers, they completed a day's journey. Then they started to look for him among their relatives and friends."

Critical reading differs from common reading (cf. Fowler 1991:2731 ). The critic moves away from the text so as to adopt a critical stance. The critic's attitude is objectifying in nature. This differs from common reading, in which the distance between reader and text is minimal. A text permits the common reader to identify with it. Readers in a sense lose themselves in the text. The critic, by contrast, stands over against the text. The critic also forms judgments on the text and substantiates these. Common readers do not do this, because they do not 
approach the text as an object. To common readers the text is not an objective entity, which it is to the critic. The transition from lectio to meditatio entails crossing from the subjectifying pole of common reading to the objectifying pole of critical analysis. By critically and analytically inquiring into the composition, development, literary genre, intratextual relations, intertextual relations and the like, the critic discovers the inner truth and deep structure of the text. In the course of this critical and analytical chewing and rumination the text yields up its secrets. The manner in which texts are analysed in scholarly exegesis is analogous to what happens in the meditative phase of lectio divina, but also differs from it. Exegetical techniques and procedures all focus on the text yielding up its meaning. To this end the exegete employs scientific methods and techniques. The questions asked in meditatio are fundamentally the same as those of scholarly exegesis, except they are not founded in scientific methodology.

\subsection{Oration and contemplation}

In the orative and contemplative phases of the reading process, commitment to God comes into play. Compared with meditatio, oratio entails a major transition. The focal issue is not extracting the meaning of the text, but relating to its contents. Guigo characterises this relationship as longing when he describes the basic movement of prayerful reading as desiderium. This longing is grounded in meditation. Prayer is kindled by meditation. The longing is explicitly directed to God,

$\ldots$ and all the while in my meditation the fire of longing, the desire to know you more fully, has increased (Guigo II, o.c. 73).

Guigo (o.c. 81) explains this with reference to Jesus' conversation with the Samaritan woman, who asked him to give her living water to drink:

You can see that it was because she had heard the Lord's words and then had meditated on them that she was moved to prayer. How could she have pressed her petition, had she not first been fired by meditation?

For our purpose it is particularly pertinent to explore the contemplative phase. First it is important to realise that what happens in contemplatio is not an automatic outcome of completing the successive phases of lectio divina. There is an initiative "from the other side." 
While this initiative relates to the longing that marks the orative phase and is a response to it, it does not depend on it. In a manner of speaking, God breaks in on the prayer. Guigo (o.c. 73-74) writes:

But the Lord, whose eyes are upon the just and whose ears can catch not only the words, but the very meaning of their prayers, does not wait until the longing soul has said all its say, but breaks in upon the middle of its prayer, runs to meet it in all haste.

A second point to be noted is the paradoxical nature of what happens. Guigo speaks of the soul dying to itself and the same time coming to life miraculously. He refers to the Lord intoxicating the soul and at the same time bringing it to its senses. It is in this context that he mentions the figure of speech known as antiphrasis. Antiphrasis is a stylistic device in which words are used in a different, often an opposite sense to their usual meaning. Through the "interpenetration of two opposing movements" (Waaijman 2002:723) the hallmark of mysticism in Guigo's view, everything acquires a different meaning.

Can it be that the heralds and witnesses of this consolation and joy are sighs and tears? If it is so, then the word consolation is used in a completely new sense, the reverse of its ordinary connotation. What has consolation in common with sighs, joy with tears, if indeed these are to be called tears and not rather an abundance of spiritual dew, poured out from above and overflowing, an outward purification as a sign of inward cleansing (Guigo II, o.c. 74-75).

The experience resulting from intensive reading of Biblical texts, as outlined in the previous section, seeks expression. Often the experience affects people's behaviour. Their dealings with people and society change. They become alert to the plight of the socially marginalised. Conscience cannot disregard perceived and experienced injustice. People rearrange the hierarchy of values by which they live and become critical of the generally accepted hierarchy of values in their environment.

Sometimes the experience seeks expression in artistic creation. Artworks like sculptures, paintings, icons and pictures can be products of intensive reading that culminated in experience of the Mystery. The experience can also express itself in language, in the creation of Biblically inspired stories, poems and the like. These are texts inspired by the reading of Biblical texts, which in their turn may cause others to engage in mystical reading. 


\section{LITURGY AS A MYSTAGOGICAL PROCESS}

Lectio divina and spiritual hermeneutics can be brought into action as preparation for liturgical celebrations. But it is also true that the reading process aimed at in lectio divina, takes place during the liturgical celebration itself. These two aspects need more attention now.

"Gathered around Scripture" is an initiative that developed a method to read Scripture in a group that has been active over the last forty years. The method is used to prepare liturgical celebrations too, with the collective reading of Scripture as a starting point. It is one of the many concrete applications of lectio divina. ${ }^{5}$ In a publication of this group it is noted what is expected from the participants and what really happens if people read texts from the Bible together. A first requirement is that participants display a willingness to listen. This is important because of the dialogical character of the collective meditation on Scripture. It is also regarded as necessary that participants should be willing to share their life experience because we pore over the text with the eyes of our experience, and Scripture always seeks to touch us in our experience. This resonates with what Mesters observed (cf. above). The understanding of Scripture, it is argued, needs a context, or more precisely, a lived context. The participants' world may relate to the personal, individual experience, but also to the experience of a group, or the experiences gained in a society or a culture. It is emphasised that this has nothing to do with abstract tales, but rather with lived experience. Finally every participant is expected to have a seeker's attitude. A certain curiosity is asked for - a curiosity that helps to look for the deeper layers of experience in Biblical texts. In this connection the possible obstructive character of exegetical knowledge that may impede an open attitude in reading and that may promote stereotypical explanation, is pointed out. Knowledge, acquired via exegetical and scholarly erudition, was not ruled out, but the needle that always plays in the same

5 Waaijman (1992). For a presentation of this way of reading Scripture against the background of the allegorical exegesis in the line of Origines, and more specially of Didymus the Blind, see Tigcheler (1977:30-56). Bertens (1986) has placed the method against the background of the Jewish-Christian tradition of reading Bible. She scrutinised the way the method functions as a model for appropriating Biblical tradition. 
grooves obstructs the deeper exploration of the experience in the text. ${ }^{6}$ The question of what really happens if people read Scripture together is also discussed. The complicated tangle of communication in such a meeting is unravelled in a number of interactions which are always present at the same moment:

1) Something happens between the individual participant and Scripture. Every participant reads the Bible passage as intensely as possible and allows it to have its way with him.

2) Something happens among the participants themselves. In sharing what everyone has discovered, the participants become companions in each other's viewpoints and experiences. A commonality of shared experiences in reading comes into being.

3) Something happens between the group and Scripture. If Scripture indeed becomes central to the group, its critical power becomes perceptible and its encouragement can do its work.

4) Something happens in the individual participant. The transformational power of the contact with Scripture is most perceptible here. Sometimes the participants start to look at reality in another way. They start to experience in another way or even to act in another way.

The dialogical aspects of the whole process are emphasised. The participants look for the emotion in Scripture together in order to be moved themselves. In the group they experience this emotion in each other. A "together" that safely can be called "becoming church" ${ }^{\circ}$ comes into being.

The conversation has a certain structure (Waaijman 2002:19-26). After the reading aloud of the text, there follow two phases. ${ }^{9}$ The scope of the first phase is to scrutinise the layer of experience in the text of Scripture and to trace deeper experiences. There are two steps in this

6 For these expectations concerning the attitude of the participants in reading, see Waaijman (1992:11-15).

7 For these moments of interactions, cf. Waaijman (1992:15-17).

8 For the "ecclesio-genetical" aspects of meetings in which the Bible is related to the experience of belief and life, cf. Derksen (2003).

9 See the scheme at the end of this paper. 
regard. In a first step the participants read the text in silence. This individual reading is text oriented. Inexperienced groups are advised to start by asking questions on composition, dramatis personae, context, intertextual relations, social setting, keywords, and so on. Every participant writes down his findings. After about ten minutes, when everybody finished doing this, the chair of the discussion invites everyone to share his findings. The second step follows. The group looks for the layer of experience in Scripture collectively. At the end the chair can give a summary of the discoveries of the group.

It is advised to have a short break after the first phase. Then the second phase follows. This phase is oriented on the layer of experience in the participants more explicitly. They explore what the reading of Scripture and the discussion of it has stirred up in them. Again the second phase consists of two steps. In the first step the participants deal with their layer of experience in silence, asking what feelings, images and emotions the text evoke in them. What symbols come up? With which characters in the text are they familiar? Again it is suggested that everyone wrote down some short notes. After about ten minutes the discussion leader invites participants to share their experiences. The second step is a dialogue. The idea is to understand each other's experiences better so that experiences told, became experiences really shared.

It is clear that the method described above can be used very well as preparation for celebrations or proclamation very well (Waaijman 2002: 36-42). If a group has the task to prepare liturgical celebrations, after the second phase a third phase can be added, in which the subject matter of the celebration is chosen. The assignment of the participants is to search for liturgical material against the background of the reading of Scripture, the discussion and the chosen theme. This material could be other texts, songs, psalms, stories, prayers, symbols, drawings, etc. All these elements are put together, possibly in a next meeting, where they are tested, approved and arranged into the order of the service.

If the method is used to prepare a homily too, it could be useful to arrange the first phase in such a way that the essential message of the text is formulated. In the second phase an attempt can be made to formulate one core experience in the same way. On the basis of this the participants can provide building stones for the proclamation and agree on how the proclamation will be arranged. 
In the second part of this last section the mystagogical aspects of the liturgical celebrations need more discussion. The liturgical celebration executes the various phases of the lectio divina and thus introduces to the mystery of Scripture. ${ }^{10}$ We recognise the initial situation in the opening rites of the celebration. From individual situations the participants have come together and now they are collected as a community and as the people of God. The lectio is present in the performance of the Word of God in the readings. The meditatio is the rumination of this Word till it yields up its meaning. This happens in the homily in which the meaning of the Word of God is sought and explained, but it also takes place in the songs and the confession of faith which allude to the Word and intensify their impact. The oratio relates to prayer. In praying the longing for God and the commitment to God, kindled by meditation, are enunciated as commitment. The intercessions, in which the community prays for the needs of the world, the church and the community itself, are manifestations of this commitment. As a praying community the church expresses its solidarity with the sighing of suffering humanity, with its longing for wholeness, justice and peace. Contemplation should not be linked to one specific moment of the celebration, but with every moment that the sacramental character of the celebration is perceptible. This is about the presence of the transcendental mystery which cannot be understood or enclosed by human beings. Finally the closing of the celebration is not only the completion of it. It also points to the mission of the community that has appropriated the Word of God. This mission can be understood as the impact of the process of appropriation and transformation that took place in the lectio divina.

In conclusion, it should be noted that every celebration is fragmentary. No linguistic utterance and no ritual celebration can express the Ineffable. Liturgy, like language, is not able to express the inexpressible character of God, though it wants to do so. For this reason liturgy requires repetition. In what is said and what is celebrated, the

10 De Keyzer related the four steps of Guigo the Carthusian to the spirituality present in the rite of the celebration of the Eucharist (De Keyzer 2000:77-106, esp. 83-85 and 2001: esp. 57-59.) We extend his opinions to each form of liturgical celebration in which Scripture plays a role. 
things that want to be said and to be celebrated, are not said and are not celebrated. Therefore these things have to be said and celebrated again and again, and every time in another way. The essential aporia is not only the source of repetition, but also the source of creativity. 


\section{Basic scheme}
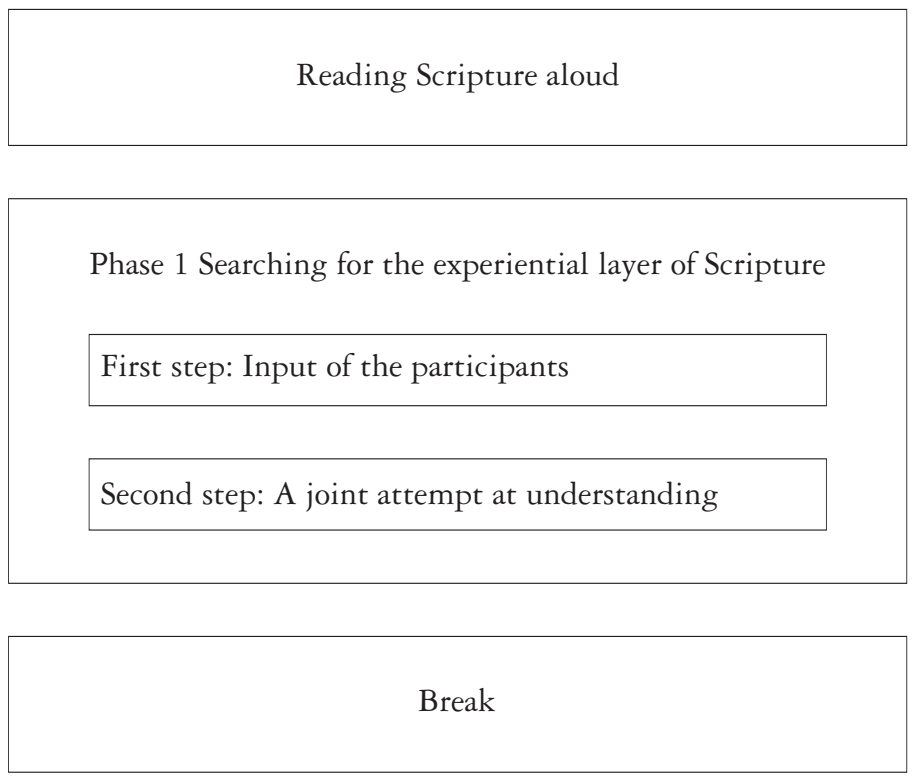

Phase 2 Exploring our own experience

First step: Input of the participants

Second step: A joint attempt at understanding 


\section{BIBLIOGRAPHY}

\section{BERTENS A}

1986. Brandde ons hart niet in ons ...? . Doctoraalscriptie Heerlen: Hogeschool voor Theologie en Pastoraat.

BIANCHI E

1996. Pregare la parole: introduzione alla "lectio divina". $12^{\text {th }}$ rev. and amplified edition, Turin: Gribaudi.

\section{BLOMMESTIJN H \& F MAAS}

2003. Mystiek en taal. In: J. Baers, G. Brinkman, A. Jelsma \& O. Steggink (reds.), Encyclopedie van de mystiek. Fundamenten, tradities, perspectieven (Kampen, Tielt: Kok, Lannoo), pp. 290-301. (First published in: Speling 40 [1988]: 90-98.)

\section{BOLAND A}

1976. Lectio Divina et lecture spirituelle. III La lecture spirituelle à l'époque moderne. Dictionnaire de Spiritualité 9:496-506.

\section{De KeyZer A}

2000. The spirituality of the Eucharist. Studies in Spirituality 10:77-106.

2001. Ga met ons jouw weg. Opbouw, betekenis en vormgeving van de eucharistie. Kampen: Kok.

\section{DERKSEN N}

2003. Woon hier onder mijn Woord: bibliodrama en andere vormen van pastoraal groepswerk voor parochie en gemeente. Kampen: Kok.

\section{ECO U}

1995. The island of the day before. London: Secker \& Warburg.

\section{FOWLER R}

1991. Let the reader understand. Reader-Response criticism and the Gospel of Mark. Minneapolis: Fortress Press.

\section{GROLLENBERG L}

1992. Over "historisch" bijbellezen. In: N Derksen \& J. Zuiker (reds.), Gaandeweg. Opstellen aangeboden aan dr Herman (Frans) Andriessen bij gelegenheid van zijn vijfenzestigste verjaardag. Kampen: Kok.

\section{GUIGO II}

1970. Epistola de vita contemplativa/Scala clautralium. In: Sources Chrétiennes 163. (Paris: Les Éditions du Cerf). Nouvelle édition 2001.

1981. The ladder of monks. A letter on the contemplative life and twelve meditations. Translated, with an introduction by E. Colledge \& J. Walsh. Kalamazoo, Michigan: Cistercian Publications.

\section{Mesters C}

1999. Lectio Divina. Melbourne: Carmelite Comunications. 
2004. The Carmelite parish: a prayerful community. On the use of the Bible in Carmelite pastoral practise. Paper read at the Carmelite Congress on the Parish. Sassone (Italy), September 2004.

\section{NisSEN P A}

2003. Art. Guigo II. In: J. Baers, G. Brinkman, A. Jelsma \& O. Steggink (reds.), Encyclopedie van de mystiek. Fundamenten, tradities, perspectieven (Kampen, Tielt; Kok, Lannoo), p. 975.

\section{REEDIJK W}

2003. Zuiver lezen. De lectio divina van Johannes Cassianus en de bijbelse hermeneutiek.

Delft: Eburon.

\section{STEGGINK O \& K WAAIJMAN}

1985. Spiritualiteit en mystiek. I. Inleiding. Nijmegen: Gottmer.

\section{TigCHELEER J}

1977. Hoe zou ik van het evangelie nog iets kunnen leren? - een oude methode in een nieuw perspectief. Speling 29:30-56.

WAAIJMAN K (ED.)

1992. Gathered around Scripture. A method for reading Scripture together. Boxtel, Almelo: Katholieke Bijbel Stichting, Nederlandse Karmelprovincie.

\section{WAAIJMAN K}

2003. Mystieke ervaring en mystieke weg. In J. Baers, G. Brinkman, A. Jelsma \& O. Steggink (reds.), Encyclopedie van de mystiek. Fundamenten, tradities, perspectieven. (Kampen, Tielt: Kok, Lannoo), pp. 57-79.

2002. Spirituality. Forms, foundations, methods. Louvain, Paris, Dudley: Peeters.

Keywords

Bible

Spirituality

Spiritual reading of the Bible

Luke

Mysticism and language

Lectio Divina
Trefwoorde

Bybel

Spiritualiteit

Spirituele lees van die Bybel

Lukas

Mistiek en taal

Lectio Divina 